\title{
Absence of repellents in Ustilago maydis induces genes encoding small secreted proteins
}

\author{
Wieke R. Teertstra • Pauline Krijgsheld • \\ Han A. B. Wösten
}

Received: 24 January 2011/Accepted: 9 April 2011/Published online: 28 May 2011

(C) The Author(s) 2011. This article is published with open access at Springerlink.com

\begin{abstract}
The repl gene of the maize pathogen Ustilago maydis encodes a pre-pro-protein that is processed in the secretory pathway into 11 peptides. These so-called repellents form amphipathic amyloid fibrils at the surface of aerial hyphae. A SG200 strain in which the repl gene is inactivated ( $\Delta$ repl strain) is affected in aerial hyphae formation. We here assessed changes in global gene expression as a consequence of the inactivation of the repl gene. Microarray analysis revealed that only 31 genes in the $\Delta$ repl SG200 strain had a fold change in expression of $\geq 2$. Twenty-two of these genes were up-regulated and half of them encode small secreted proteins (SSPs) with unknown functions. Seven of the SSP genes and two other genes that are over-expressed in the $\Delta$ repl SG200 strain encode proteins that can be classified as secreted cysteine-rich proteins (SCRPs). Interestingly, most of the SCRPs are predicted to form amyloids. The SCRP gene um00792 showed the highest up-regulation in the $\Delta$ repl strain. Using GFP as a reporter, it was shown that this gene is overexpressed in the layer of hyphae at the medium-air interface. Taken together, it is concluded that inactivation of repl hardly affects the expression profile
\end{abstract}

W. R. Teertstra $(\bowtie) \cdot$ P. Krijgsheld · H. A. B. Wösten Department of Microbiology and Kluyver Centre for Genomics of Industrial Fermentations, Faculty of Science, University of Utrecht, Padualaan 8, $3584 \mathrm{CH}$ Utrecht, The Netherlands

e-mail: w.r.teertstra@uu.nl of $U$. maydis, despite the fact that the mutant strain has a strong reduced ability to form aerial hyphae.

Keywords Aerial hypha $\cdot$ Repellent $\cdot$ Hydrophobinlike protein $\cdot$ Ustilago maydis $\cdot \mathrm{SSP} \cdot \mathrm{SCRP}$

\section{Introduction}

The life cycle of the pathogenic heterobasidiomycete Ustilago maydis is characterized by distinct morphological and nuclear states. Fusion of compatible yeast-like sporidia results in the formation of a pathogenic filamentous dikaryon. Upon formation of an appressorium the host (Zea mays [maize] and Euchlaena mexicana [Mexican teosinte]) is invaded. The fungus proliferates and branches inside the plant tissue, resulting in the formation of diploid teliospores. These spores are dispersed into the environment. After germination, meiosis occurs resulting in the formation of haploid sporidia (Banuett and Herskowitz 1988; Banuett 1992; Christensen 1963).

Only when two partners harbor different alleles of the $a$ - and $b$-loci, mating and pathogenic development can occur. Cell fusion is controlled by the $a 1$ and $a 2$ mating-type loci (Bölker et al. 1992). These loci encode a pheromone and a receptor for the pheromone of the opposite mating type. The multi-allelic $b$ locus regulates the post-mating processes of filament formation and pathogenic development. The $b$ locus 
encodes two unrelated homeodomain proteins, $b E$ and $\mathrm{bW}$, that form active hetero-dimers when derived from different alleles (Gillissen et al. 1992; Kämper et al. 1995).

Repl is one of the genes that is regulated by the bE/ bW heterodimer (Bohlmann 1996; Brachmann et al. 2001; Romeis et al. 2000; Wösten et al. 1996). The repl gene encodes a pre-pro-protein, which consists of a signal sequence for secretion and 12 repeated sequences. Processing at KEX2 recognition sites in the secretory pathway results in 10 peptides of 34-53 amino acids and one larger protein of 229 amino acids (Wösten et al. 1996). These cleavage products that are collectively known as repellents are secreted into the cell wall of filaments. Here they form amyloid fibrils (Teertstra et al. 2009), which are involved in attachment to hydrophobic surfaces and in formation of hydrophobic aerial hyphae (Teertstra et al. 2006, 2009; Wösten et al. 1996).

Strains in which the repl gene has been inactivated form colonies with only few aerial hyphae (Teertstra et al. 2006; Wösten et al. 1996). We here show that expression of only 31 genes is changed at least two-fold in the $\Delta$ repl strain when compared to the parental SG200 strain under conditions of aerial growth. Most of these genes are up-regulated and encode for small secreted proteins without a predicted enzymatic function.

\section{Methods}

Strains and growth conditions

Ustilago maydis strain SG200 (almfa2 bE1/bW2) (Bölker et al. 1995) and its derivatives (see below) were used in this study. SG200 is a haploid FB1 (albl) strain (Banuett and Herskowitz 1989), which harbors an active $b$ mating type complex. Consequently, the strain grows yeast-like in liquid medium and forms filaments at the water-air interface without the need for mating. U. maydis strains were routinely grown at $25^{\circ} \mathrm{C}$ using liquid YEPSL medium $(0.4 \%$ yeast extract, $0.4 \%$ peptone, $2 \%$ sucrose) or potato dextrose agar (PDA, Sigma) that had either or not been supplemented with $1 \%(\mathrm{w} / \mathrm{v})$ charcoal. For isolation of RNA for microarray analysis, cells were grown at $22^{\circ} \mathrm{C}$ on nitrate minimal medium $\left(\mathrm{NM}^{+}\right.$; Holliday 1974) containing $2 \%$ agar (w/v), $1 \%$ charcoal (w/v), $20 \mathrm{mg} \mathrm{l}^{-1}$ histidine, $380 \mathrm{mg} \mathrm{l}^{-1}$ leucine, $20 \mathrm{mg} \mathrm{l}^{-1}$ tryptophan,
$50 \mathrm{mg}^{-1}$ uracil and $76 \mathrm{mg} \mathrm{l}^{-1}$ Yeast Synthetic Dropout Medium Supplements (Sigma, Y2001). For GFP expression analysis, $1 \mu \mathrm{l}$ of cell suspension $\left(2 \times 10^{7}\right.$ cells $\mathrm{ml}^{-1}$ ) was seeded on each side of a $0.25 \mathrm{~mm}$ thin $20 \times 20 \mathrm{~mm}$ square of solidified $(1.5 \%$ agarose $) \mathrm{NM}^{+}$ medium that was sandwiched between a glass slide and a cover slip. Cells were grown at $25^{\circ} \mathrm{C}$ under humid conditions.

\section{Constructs}

SG2004repl was generated as described (Müller et al. 2008a). The PCR fragment that was used to inactivate repl was amplified with oligonucleotide primers RepMUF-fw and RepMDF-rev (Table 1) using Phusion $^{\mathrm{TM}}$ polymerase (Finnzymes). The resulting PCR fragment, consisting of a nourseothricin resistance cassette (Brachmann et al. 2004) flanked by the upstream and downstream sequences of the repl gene, was used to transform the SG200 strain.

Vector pUC19-Rep-c was used to complement the SG2004repl strain. A 3674 bp PCR fragment was amplified for its construction. This fragment consisted of a $1680 \mathrm{bp}$ repl promoter region and the coding sequence of this gene. For this, Phusion ${ }^{\text {TM }}$ polymerase (Finnzymes) was used with genomic FB1 DNA as a template and oligonucleotide primers pRep-fw and cRep-rev (Table 1). The latter primer introduces a NotI-site at the $3^{\prime}$ end. The 3674 bp PCR-fragment was introduced in the SmaI-site of pUC19. In the next step, a NotI fragment encompassing a carboxin-resistance cassette (Brachmann et al. 2004) was introduced into the respective site of the pUC19 derivative, resulting in pUC19-Rep-c.

The promoter region of gene um00792 was amplified from genomic DNA of FB1 using Phusion ${ }^{\text {TM }}$

Table 1 Primers used in this study

\begin{tabular}{ll}
\hline Primer name & Sequence \\
\hline RepMUF-fw & TTTGCGTATTCCACCTGCAGTAGCC \\
RepMDF-rev & CAACTACTGGGAAAAGTATGGAGCGG \\
pRep-fw & GGTACCGCAGCAATCACAGAG \\
cRep-rev & GCGGCCGCATGAGGAAACCCTAAC \\
pr792-fw & AAACTTGGGCCCGCTACCAG \\
pr792-rev & GGAGGAACAACGAGGATGAC \\
RepUF-fw & GGATGTAGCTGTCGTGCTTCCA \\
RepUF-rev & GGCCATCTAGGCCGTGATAATGT \\
\hline
\end{tabular}


polymerase (Finnzymes) with oligonucleotide primers pr792-fw and pr792-rev (Table 1). The resulting 1837 bp fragment was introduced in the SmaI site of pUC19, resulting in vector pUC19-pr792. The $1791 \mathrm{bp} \mathrm{ApaI/NcoI} \mathrm{promoter} \mathrm{fragment} \mathrm{of} \mathrm{um00792}$ was digested from pUC19-pr792 and introduced in the corresponding sites of pMF3c (Brachmann et al. 2004). As a result, enhanced GFP (eGFP) was placed under control of the um00792 promoter. The resulting construct pMF3c-pr792 was linearized in the carboxin resistance cassette with AgeI, thus targeting the DNA to the $s d h 2$-locus of $U$. maydis upon transformation.

Transformation of $U$. maydis

Ustilago maydis was transformed according to Brachmann et al. (Brachmann et al. 2004). Transformants were selected on PDA plates supplemented with nourseothricin $\left(150 \mu \mathrm{g} \mathrm{ml}^{-1}\right)$ and carboxin $\left(2 \mu \mathrm{g} \mathrm{ml}^{-1}\right)$, respectively. Deletion of the repl gene was confirmed by Southern analysis. Chromosomal DNA of $U$. maydis was isolated as described (Hoffman and Winston 1987) and blotted onto Hybond N+ (Amersham). Hybridization was performed at $60^{\circ} \mathrm{C}$ in $0.5 \mathrm{M}$ phosphate buffer, $\mathrm{pH} 7.2$, containing 7\% SDS and 10 mM EDTA. A 936 bp ${ }^{32} \mathrm{P}-\alpha-\mathrm{dCTP}$ labeled PCRfragment was used as a probe, which was derived from the repl promoter region of FB1 using the primers RepUF-fw and RepUF-rev (Table 1).

Northern analysis

Ustilago maydis cultures were homogenized with a microdismembrator (B.Braun). RNA was extracted with Trizol (Invitrogen) according to the manufacturer's protocol. Hybridization was performed using standard protocols (Sambrook et al. 1989). ${ }^{32} \mathrm{P}-\alpha-$ dCTP labeled fragments of genes um00792, um00913 and um03817 were used as a probe.

Microarray analysis

$2 \times 10^{7}$ cells of exponentially growing cultures of strains SG200 and SG2004repl were seeded on solid $\mathrm{NM}^{+}$-charcoal medium and grown for $48 \mathrm{~h}$. Cells were harvested, frozen in liquid nitrogen, and homogenized with a dismembrator (Retsch). RNA was isolated with Trizol, after which double stranded cDNA was made according to the Affymetrix protocol (Affymetrix). The cDNA was purified over a cDNA clean up spin column, after which biotin labeled antisense cRNA was obtained using the Enzo BioArray HighYield RNA transcript labeling kit (ENZO Diagnostics). Concentration of the cRNA was determined using the NanoDrop N-1000 (Thermo Scientific) and quality of the cRNA was determined using the 2100 Bioanalyzer (Agilent Technologies). cRNA was fragmented according to the Affymetrix protocol and the resulting 30-200 bp fragments were hybridized to the Affymetrix custom array (MIPIUstilagoA). Array data have been deposited in NCBI's Gene Expression Omnibus (Edgar et al. 2002) and are accessible through GEO Series accession number GSE21490 (http://www.ncbi.nlm. nih.gov/geo/query/acc.cgi?acc=GSE21490). Data analysis of biological triplicates was performed as described previously (Eichhorn et al. 2006). Genes with a $P$ value of $<0.01$, whose mean expression was at least 2-fold changed, were filtered in Excel.

Analysis of protein sequences

Protein sequences of $U$. maydis were obtained from the MUMDB database (http://mips.gsf.de/genre/proj/ ustilago) and analyzed for functional domains with SCOP (Murzin et al. 1995), SMART (Ponting et al. 1999), PFAM (Bateman et al. 2002), SignalP (Bendtsen et al. 2004), TANGO (Fernandez-Escamilla et al. 2004) and Waltz (Maurer-Stroh et al. 2010).

Fluorescence microscopy

Fluorescence microscopy was carried out using a Zeiss Axioscope 2PLUS equipped with a $\mathrm{HBO}$ $100 \mathrm{~W}$ mercury lamp and a Leica LFC 420C camera $(2592 \times 1944$ pixels $)$. GFP fluorescence was monitored using a FITC filter set.

\section{Results}

Absence of repellents has a minor effect on overall gene expression in $U$. maydis

Gene repl was deleted in strain SG200 by introducing a PCR-fragment consisting of a nourseothricin resistance cassette flanked by upstream and downstream sequences of repl (see Methods). Five out of 
12 transformants showed loss of surface hydrophobicity and reduction of aerial hyphae formation on PDA charcoal. Southern analysis confirmed deletion of repl in these strains. Introduction of pUC19-Rep-c encompassing the repl gene restored formation of aerial hyphae, showing that the phenotype was solely caused by the gene deletion (Data not shown).

To monitor the effect of the repl deletion on overall gene expression during aerial hyphae formation, DNA microarrays (representing $\sim 90 \%$ of the genes of $U$. maydis) were hybridized with RNA from SG200 and a SG2004rep1 strain. To this end, both strains had been grown for 2 days on a synthetic medium containing charcoal. SG200 formed abundant aerial hyphae, whereas aerial hyphae formation in the mutant strain was severely affected (Fig. 1b). Thirty-one genes showed a fold change $\geq 2$ when expression of the two strains was compared. Twentytwo of these genes were up-regulated, whereas 9 were

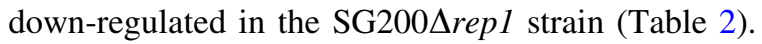
The microarray data were confirmed with Northern analysis by probing for 3 genes (Fig. 1a). This showed that expression of genes um00792 and um00913 was increased in the SG2004repl strain compared to the parental strain at least 6-fold and 3 -fold, respectively, whereas expression of gene um03817 was decreased at least 10-fold. Expression of genes um00792 and um00913 was higher on PDA than on NM+-charcoal, which correlated with the number of aerial hyphae that were formed. In contrast, expression of um03817 was more pronounced on solidified $\mathrm{NM}^{+}$-charcoal. This indicates that expression of at least um03817 is not only influenced by the repl deletion, but also by the composition of the medium.

Of the genes that were down-regulated in the SG2004repl strain, 2 encode secreted proteins (Table 2). One of these genes is predicted to have enzymatic activity. This gene, um11112, is related to genes encoding Versicolorin B synthase. The $U$. maydis gene is proposed to encode a protein with aryl-alcohol oxidase activity (Müller et al. 2008b). The other gene, um04248, encodes a repetitive protein with no similarity to known proteins (Müller et al. 2008a). Eighteen out of the 22 genes with an increased expression in the SG2004repl strain encode secreted proteins (Table 2), as predicted by SignalP and TargetP (see Müller et al. 2008b). Several of these genes have already been deleted in $U$. maydis, either as a single or part of a multiple gene deletion (Table 2; Kämper et al. 2006; Leuthner et al. 2005; Vraneš 2006). Two up-regulated genes encode secreted proteins with an enzymatic function. Gene um00913 encodes glyoxaloxidase 2 (Leuthner et al. 2005), whereas um04422 is predicted to encode an endo-xylanase (Müller et al. 2008b). Remarkably, the

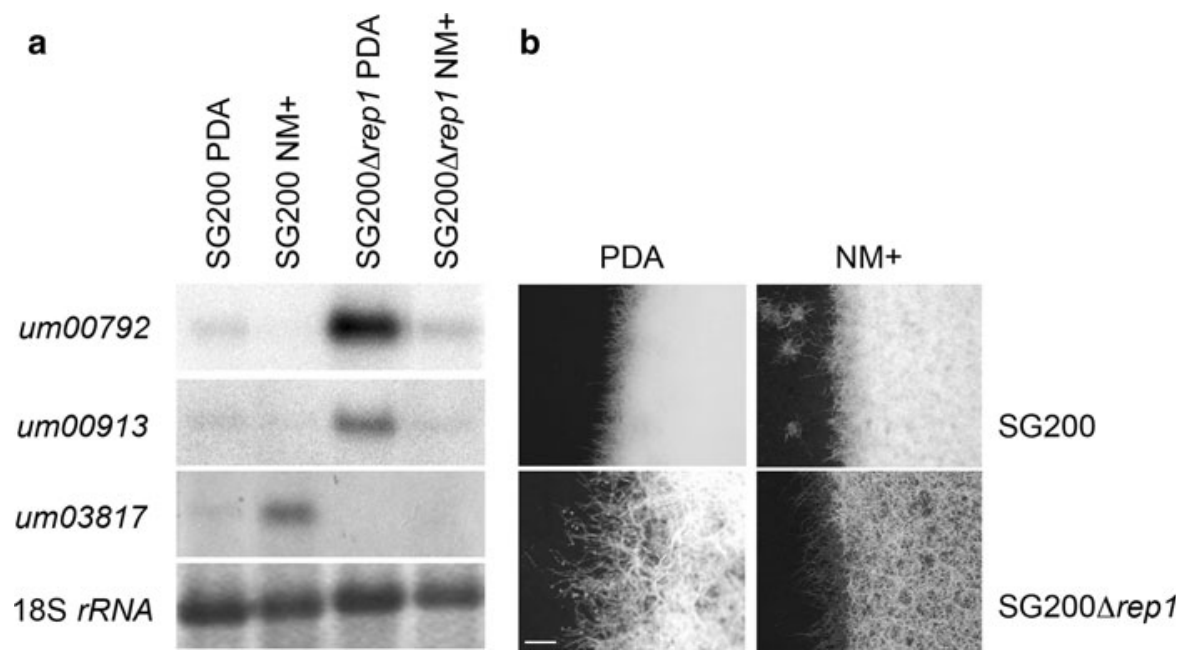

Fig. 1 Inactivation of repl results in reduced aerial hyphae formation and in changes in gene expression. a Northern analysis of genes um00792, um00913 and um03817 in strains SG200 and SG2004rep1, 18S rRNA serving as a control. Cultures were grown on PDA-charcoal and NM+-charcoal for
48 h. b Detail of colonies of the SG200 and SG2004rep1 strain grown on PDA and NM+-charcoal plates. Colonies of strain SG200 form abundant aerial hyphae, whereas in the rep1 deletion strain aerial hyphae formation is severely reduced. Bar represents $0.5 \mathrm{~mm}$ 


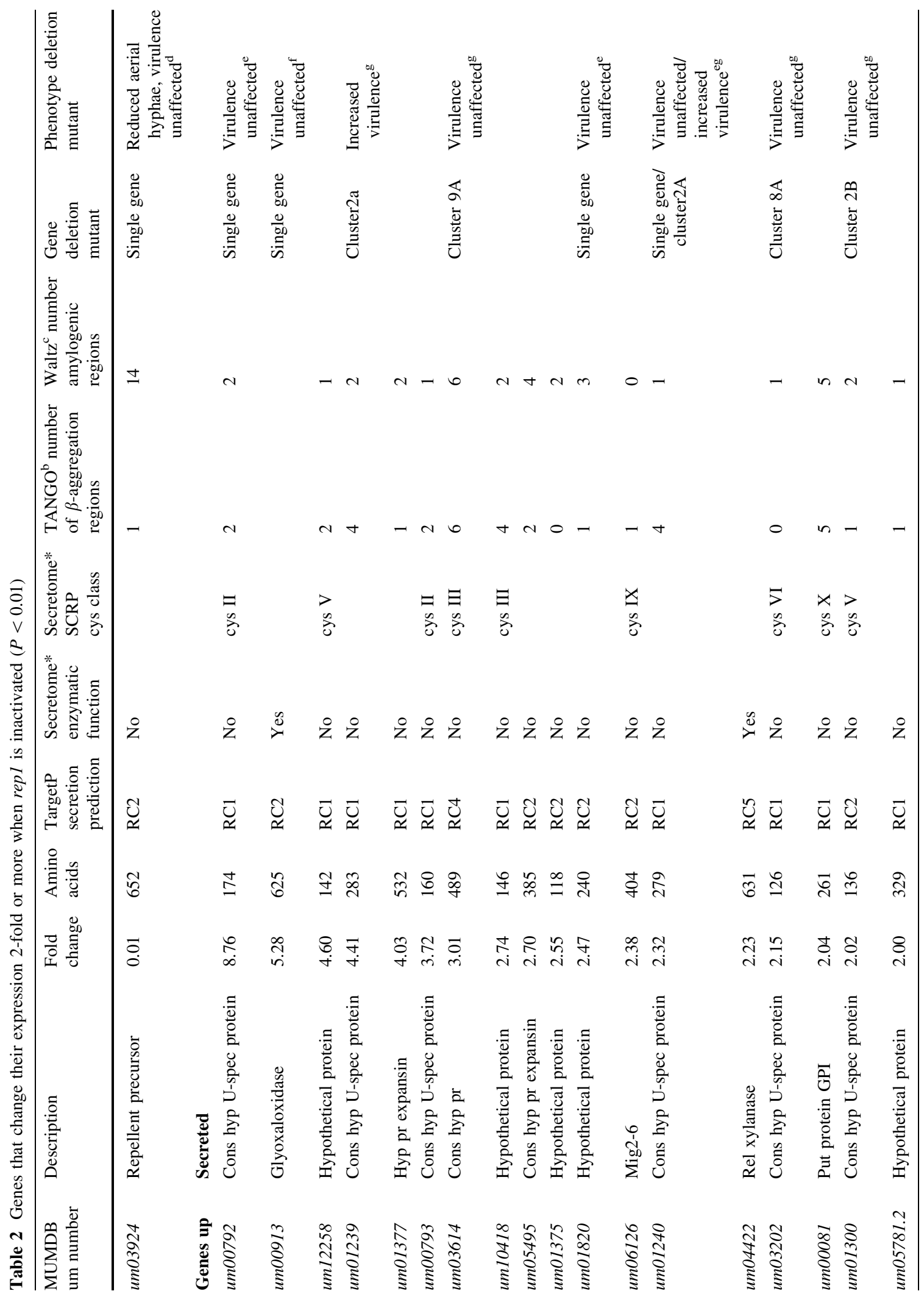




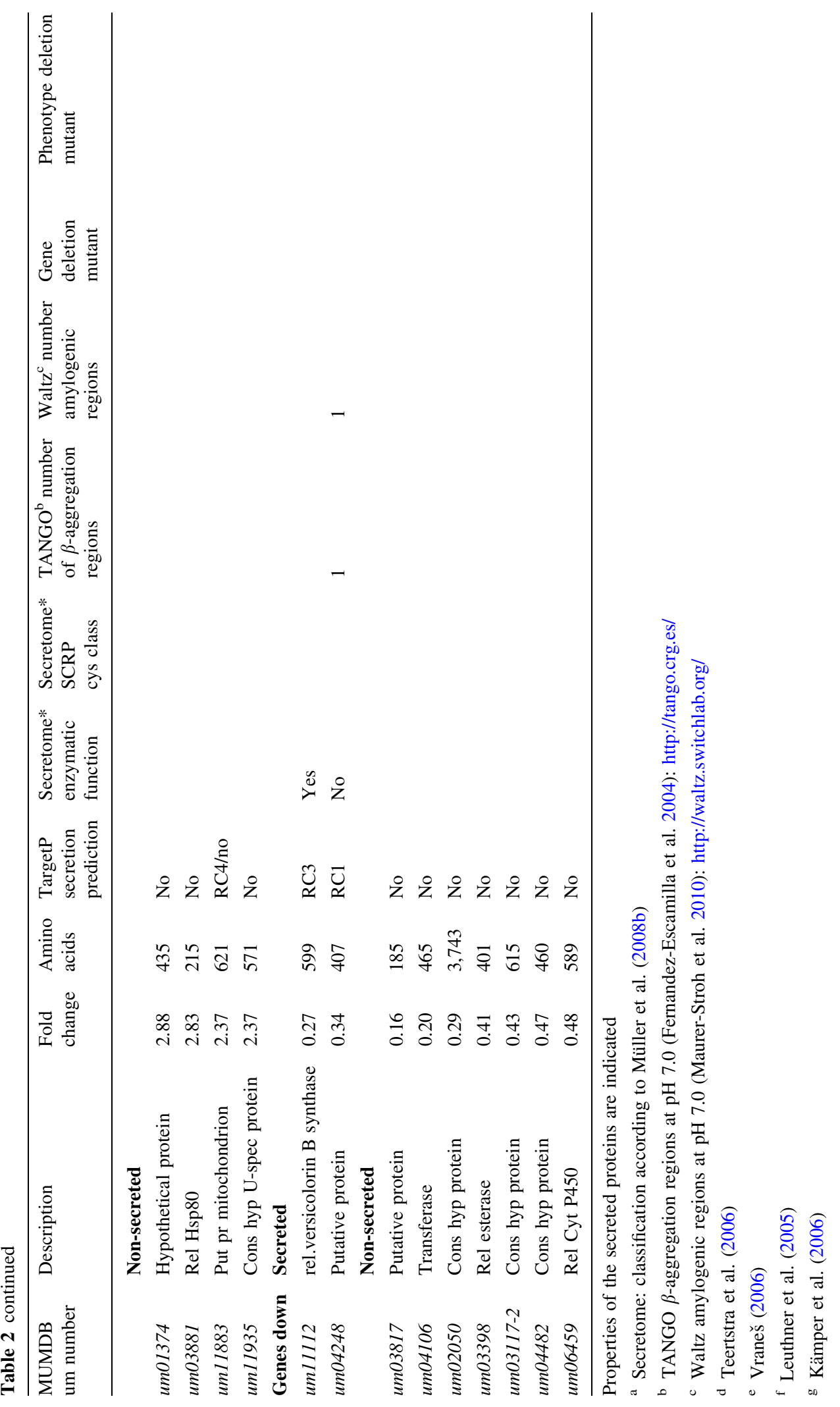


other 16 genes encode secreted proteins with no apparent enzymatic function. Eleven of them belong to the small secreted proteins (SSPs), which have an arbitrary size limit of 300 amino acids. Of these genes, 7 encode secreted cysteine-rich proteins (SCRPs), whereas another 2 up-regulated SCRPs exceed 300 aa (Table 2; Müller et al. 2008b). The TANGO and Waltz algorithms were used to assess whether the 16 secreted proteins that are predicted not to have an enzymatic function have the potential to form amyloid fibrils. The TANGO algorithm predicts regions within a protein that are prone to intermolecular $\beta$-sheet formation. These intermolecular $\beta$-sheets can result in protein aggregation (Fernandez-Escamilla et al. 2004). It was found that five consecutive residues with a TANGO score above $5 \%$ are a good predictor of aggregation (FernandezEscamilla et al. 2004). Using standard settings (see http://tango.crg.es/), 14 out of the 16 mature proteins had one or more of these aggregation prone regions and 5 of them had 4 or more. The Waltz algorithm is a position-specific scoring matrix that has been developed to distinguish between amyloid sequences and amorphous $\beta$-sheet aggregates (Maurer-Stroh et al. 2010). Using standard settings (http://waltz. switchlab.org/), it was shown that 15 out of the 16 proteins had between 1 and 6 amylogenic regions. Only Mig2-6 that is encoded by um06126 (Zheng et al. 2008) was found not to have such a region. Taken together, the TANGO and Waltz algorithms predict that most of the proteins that are encoded by the up-regulated genes within the repl mutant have the propensity to form amyloids.

Gene um00792 is highly induced in filaments of the SG2004repl strain that grow at the water-air interface.

The SCRP gene um00792 shows the highest change in expression when strains SG200 and SG2004repl are compared by micro-array analysis (Table 2). Its expression is 8.75 fold increased in the SG2004repl strain. Expression of this gene was monitored using GFP as a reporter. To this end, strains SG200 and SG2004repl were transformed with construct pMF3c-pr792. This vector contains the eGFP gene, which is placed behind the um00792 promoter. Transformants uG114 and uG115, which

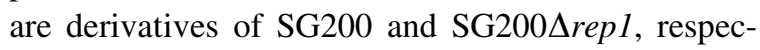
tively, showed a fluorescence pattern representative for the majority of the fluorescent transformants. These strains were therefore selected for further study. They were grown along a thin slab of nitrate minimal medium, sandwiched between an object glass and a cover slip. Aerial hyphae and hyphae growing in the substrate showed similar GFP fluorescence in strains uG114 and uG115 (Fig. 2a). However, at the mediumair interface, a 10-fold increase in fluorescence was shown in the SG2004repl derivative uG115 when compared to the wild-type derivative $\mathrm{uG114}$. This layer consists of yeast cells and filaments that have not yet escaped into the air (Fig. 2b, c). Both cell types a
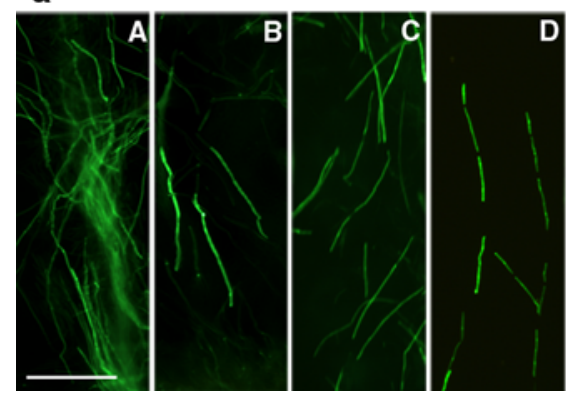

b

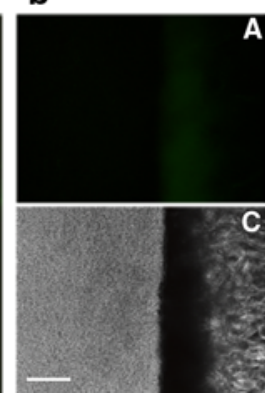

Fig. 2 Localization of expression of um00792 in the SG200

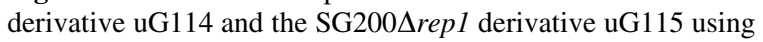
eGFP as a reporter. Cells were seeded along a thin layer of solidified medium between a glass slide and a cover slip and grown for $40 \mathrm{~h}$. Cells were monitored by phase contrast and fluorescence microscopy. a Individual hyphae of strain uG114 $(A, B)$ and uG115 $(C, D)$ growing in the substrate $(A, C)$ or in the air $(B, D)$ show similar fluorescence. b Strain uG114 $(A, C)$ and strain uG115 $(B, D)$ growing along the solidified medium visualized by fluorescence $(A, B)$ and light $(C, D)$ microscopy. Total fluorescence of the top layer, consisting of yeasts and developing hyphae, is highly increased in the uG115 strain $(B)$. c Detail of $(\mathbf{b}, B)$. Bar represents $100 \mu \mathrm{m}$ 
within this layer showed fluorescence. In contrast, gene expression was not detected in yeast cells in liquid shaken cultures (data not shown).

\section{Discussion}

Strains in which the repl gene is inactivated form few aerial hyphae (Teertstra et al. 2006; Wösten et al. 1996). We here assessed global changes in gene expression as a consequence of the inactivation of the repl gene. It is shown that deletion of this gene has a minor effect on global gene expression under conditions of aerial growth in the wild-type. Interestingly, a majority of the genes that are up-regulated at least two-fold encode small secreted proteins that are predicted to form amyloids.

Gene expression at the stage of aerial hyphae formation was monitored with microarray analysis. Only 31 genes had a fold change in expression of at least two when expression profiles of strains SG200 and SG200 $\Delta$ repl were compared. Of these genes, 7 had a fold change of at least 4 and only 1 gene had a fold change of at least 8 . This is a striking difference with gene regulation in the basidiomycete Schizophyllum commune and the filamentous bacterium Streptomyces coelicolor. These microorganisms produce repellentlike proteins; i.e. the hydrophobins in S. commune (Wösten et al. 1993, 1994a, b, 1999; Wösten and Willey 2000) and the chaplins in S. coelicolor (Claessen et al. 2003, 2004). Like repellents, hydrophobins and chaplins form functional amyloid fibrils at the hyphal surface (Butko et al. 2001; Claessen et al. 2003; Wösten and de Vocht 2000; de Vocht et al. 2002; Scholtmeijer et al. 2009). Inactivation of the genes encoding these proteins results in a phenotype similar to that of the $\Delta$ repl strain (Claessen et al. 2003; van Wetter et al. 1996, 2000; Wösten et al. 1994b). Over 4000 genes had changed their expression at least twofold under conditions of aerial growth when expression of a wild-type $S$. commune strain was compared to that of the hydrophobin knockout strain $\triangle S C 3 \triangle S C 4$ (R.A. Ohm, H.A.B. Wösten, unpublished results). In S. coelicolor 244 genes had a $\geq 2$-fold changed expression in the $\Delta c h p$ strain (de Jong et al. 2009; Claessen et al. 2006). Transcriptional regulators were among the genes with an affected expression in both $S$. commune and $S$. coelicolor. In contrast, genes encoding transcriptional activators were not affected in the $\Delta$ repl strain. How can we explain this result? In $S$. commune and $S$. coelicolor, aerial hyphae formation is the first step in a differentiation process leading to the formation of fruiting bodies and spore chains, respectively. In contrast, aerial hyphae of $U$. maydis seem to represent vegetative hyphae that happen to grow into the air.

Remarkably, most of the genes that changed their expression in the $\Delta$ repl strain encode secreted proteins without an enzymatic function. Eleven out of 22 genes that were up-regulated encode small secreted proteins (SSPs) and 9 of them belong to the class of secreted cysteine-rich proteins (SCRPs) (Müller et al. 2008b). These proteins harbor no common protein domains. For these proteins, similarity in three-dimensional structure may be more important than sequence similarity. This is in agreement with the results obtained with the TANGO and Waltz algorithms (Fernandez-Escamilla et al. 2004; Maurer-Stroh et al. 2010). These algorithms predict $\beta$-aggregation and amylogenic regions in more than $80 \%$ of the SSPs and SCRPs that are up-regulated in the $\Delta r e p l$ strain. The algorithms also predict amylogenic regions in the repellents of $U$. maydis and in the $S$. commune hydrophobin SC3, which are known to form amyloids (Wösten and de Vocht 2000; de Vocht et al. 2002; Scholtmeijer et al. 2009; Teertstra et al. 2009).

We previously showed that repellents form amyloids in the cell wall of hyphae of $U$. maydis (Teertstra et al. 2009). Interestingly, filaments of the SG2004repl strain also stained with ThT, from which it was concluded that other secreted proteins also have the capability to form amyloid fibrils. The SSPs that are up-regulated in SG2004repl could be candidates for such proteins. These results are in line with previous findings that amyloids can be generally found on microbial surfaces (Claessen et al. 2003; Chapman et al. 2002; Larsen et al. 2007; Otoo et al. 2008; Rauceo et al. 2004; Gebbink et al. 2005). Our results indicate that a variety of proteins can form such structures at a particular cell surface. It may well be that only part of them (e.g. the chaplins, hydrophobins and repellents) form an amphipathic amyloid film, thus enabling aerial growth by lowering the water surface tension. The SSPs of $U$. maydis may not be able to do so, which would explain why aerial growth in the $\Delta$ repl strain is strongly affected.

Twelve clusters are found in the genome of $U$. maydis that contain genes encoding SSPs (Kämper 
et al. 2006). Deletion of five of them changed virulence (Kämper et al. 2006). Four of these clusters contain SSPs that are up-regulated in the $\Delta$ repl strain (see Table 2). The symbiotic basidiomycete Laccaria bicolor also harbors a high number of genes encoding SSPs. Ten percent of the secreted proteins belong to this class, many of which are classified as SCRPs. A part of these genes is up-regulated during mycorrhizal interactions, whereas others are down-regulated. This suggests an important role for these proteins in the symbiosis (Martin et al. 2008). SCRPs of fungi and oomycetes have been described to function as apoplastic effectors (Kamoun 2006). Such effectors include toxins, elicitors, virulence and avirulence proteins. The cysteine residues have been proposed to enhance stability of the proteins and yield protection to plant proteases (Joosten et al. 1997; Luderer et al. 2002). Whether (some of) the U. maydis SSP and SCRP genes are also apoplastic effectors remains to be investigated.

The highest up-regulated gene in the $\Delta$ repl strain is gene um00792. It encodes a SCRP of 144 amino acids with 7 cysteines. The gene is clustered in the genome with genes um00793, um00794 and um00795. It has $28 \%$ sequence homology with gene um00793, which is also up-regulated in the SG200 $\Delta$ repl strain. Deletion of gene um00792 has no influence on pathogenicity (Vraneš 2006) but its expression depends on bizl. This gene encodes a transcription factor, which functions at the stage of filament and appressorium formation (Flor-Parra et al. 2006). It down-regulates $\mathrm{clbl}$, the mitotic cyclin, (Flor-Parra et al. 2006) and thereby causes $\mathrm{G} 2$ cell cycle arrest prior to plant invasion. Of interest, expression of um06126, um01240, um01820 and $u m 01377$ is also increased in the absence of repellents and decreased in the absence of Biz1 (This study; Vraneš 2006). The latter indicates a role for these genes in the early stages of pathogenic development.

Expression of gene um00792 was followed using GFP as a reporter. Expression of this gene was detected in strains SG200 and SG2004repl in aerial hyphae and hyphae growing in the substrate. Gene expression was not detected in yeast cells growing in liquid culture, but yeast cells growing in and on the solid substrate, where hyphal growth is initiated, did show fluorescence. Strikingly, over-expression of um00792 was only detected in the $\Delta$ repl strain in the layer of seeded cells that lay on the solid substrate. This layer contains many hyphae that seem unable to escape from the extracellular matrix. Possibly, the fungus senses absence of the repellents in the extracellular matrix, causing up-regulation of gene um00792. The protein encoded by this gene, however, is not able to complement repellents in formation of aerial hyphae (see above). Future studies should reveal the role of the SSPs and SCRPs that are up-regulated in $U$. maydis upon inactivation of the repl gene. It may well be that the genes are redundant, requiring multiple knock-outs before a phenotype will be observed.

Open Access This article is distributed under the terms of the Creative Commons Attribution Noncommercial License which permits any noncommercial use, distribution, and reproduction in any medium, provided the original author(s) and source are credited.

\section{References}

Banuett F (1992) Ustilago maydis, the delightful blight. Trends Genet 8:174-180

Banuett F, Herskowitz I (1988) Ustilago maydis, smut of maize. Adv Plant Pathol 6:427-455

Banuett F, Herskowitz I (1989) Different $a$ alleles of Ustilago maydis are necessary for maintenance of filamentous growth but not for meiosis. Proc Natl Acad Sci USA 86:5878-5882

Bateman A, Birney E, Cerruti L, Durbin R, Etwiller L, Eddy SR, Griffiths-Jones S, Howe KL, Marshall M, Sonnhammer ELL (2002) The PFAM protein families database. Nucleic Acids Res 30:276-280

Bendtsen JD, Nielsen H, Von Heijne G, Brunak S (2004) Improved prediction of signal peptides: SignalP 3.0. J Mol Biol 340:783-795

Bohlmann R (1996) Isolierung und Charakterisierung von Filamentspezifisch Exprimierten Genen aus Ustilago maydis. Dissertation, University of Munich

Bölker M, Urban M, Kahmann R (1992) The $a$ mating type locus of $U$. maydis specifies cell signaling components. Cell 68:441-450

Bölker M, Genin S, Lehmler C, Kahmann R (1995) Regulation of mating and dimorphism in Ustilago maydis. Can J Bot 73:S320-S325

Brachmann A, Weinzierl G, Kämper J, Kahmann R (2001) Identification of genes in the $\mathrm{bW} / \mathrm{bE}$ regulatory cascade in Ustilago maydis. Mol Microbiol 42:1047-1063

Brachmann A, König J, Julius C, Feldbrügge M (2004) A reverse genetic approach for generating gene replacement mutants in Ustilago maydis. Mol Genet Genomics 272:216-226

Butko P, Buford JP, Goodwin JS, Stroud PA, McCormick CL, Cannon GC (2001) Spectroscopic evidence for amyloidlike interfacial self-assembly of hydrophobin Sc3. Biochem Biophys Res Commun 280:212-215 
Chapman MR, Robinson LS, Pinkner JS, Roth R, Heuser J, Hammar M, Normark S, Hultgren SJ (2002) Role of Escherichia coli curli operons in directing amyloid fiber formation. Science 295:851-855

Christensen J. J. (1963) Corn smut caused by Ustilago maydis. The American Phytopathological Society, St Paul, Monograph No.2, 41

Claessen D, Rink R, de Jong W, Siebring J, de Vreugd P, Boersma FGH, Dijkhuizen L, Wösten HAB (2003) A novel class of secreted hydrophobic proteins is involved in aerial hyphae formation in Streptomyces coelicolor by forming amyloid-like fibrils. Genes Dev 17:1714-1726

Claessen D, Stokroos L, Deelstra HJ, Penninga NA, Bormann C, Salas JA, Dijkhuizen L, Wösten HAB (2004) The formation of the rodlet layer of Streptomycetes is the result of the interplay between rodlins and chaplins. Mol Microbiol 53:433-443

Claessen D, de Jong W, Dijkhuizen L, Wösten HAB (2006) Regulation of Streptomyces development: reach for the sky!. Trends Microbiol 14:313-319

de Jong W, Manteca A, Sanchez J, Bucca G, Smith CP, Dijkhuizen L, Claessen D, Wösten HAB (2009) NepA is a structural cell wall protein involved in maintenance of spore dormancy in Streptomyces coelicolor. Mol Microbiol 71:1591-1603

de Vocht ML, Reviakine I, Ulrich WP, Bergsma-Schutter W, Wösten HAB, Vogel H, Brisson A, Wessels JG, Robillard GT (2002) Self-assembly of the hydrophobin SC3 proceeds via two structural intermediates. Protein Sci 11:1199-1205

Edgar R, Domrachev M, Lash AE (2002) Gene Expression Omnibus: NCBI gene expression and hybridization array data repository. Nucleic Acids Res 30:207-210

Eichhorn H, Lessing F, Winterberg B, Schirawski J, Kämper J, Müller P, Kahmann R (2006) A ferroxidation/permeation iron uptake system is required for virulence in Ustilago maydis. Plant Cell 18:3332-3345

Fernandez-Escamilla AM, Rousseau F, Schymkowitz J, Serrano L (2004) Prediction of sequence-dependent and mutational effects on the aggregation of peptides and proteins. Nat Biotechnol 22:1302-1306

Flor-Parra I, Vraneš M, Kämper J, Pérez-Martín J (2006) Biz1, a zinc finger protein required for plant invasion by Ustilago maydis, regulates the levels of a mitotic cyclin. Plant Cell 18:2369-2387

Gebbink MF, Claessen D, Bouma B, Dijkhuizen L, Wösten HAB (2005) Amyloids - a functional coat for microorganisms. Nat Rev Microbiol 3:333-341

Gillissen B, Bergemann J, Sandmann C, Schroeer B, Bölker M, Kahmann R (1992) A two-component regulatory system for self/non-self recognition in Ustilago maydis. Cell 68:647-657

Hoffman CS, Winston F (1987) A ten-minute DNA preparation from yeast efficiently releases autonomous plasmids for transformation of Escherichia coli. Gene 57:267-272

Holliday R (1974) Ustilago maydis. In: King RC (ed) Handbook of Genetics. Plenum Press, New York, pp 575-595

Joosten MHAJ, Vogelsang R, Cozijnsen TJ, Verberne MC, de Wit PJGM (1997) The biotrophic fungus Cladosporium fulvum circumvents cf-4-mediated resistance by producing unstable AVR4 elicitors. Plant Cell 9:367-379
Kamoun S (2006) A catalogue of the effector secretome of plant pathogenic oomycetes. Ann Rev Phytopathol 44:41-60

Kämper J, Reichmann M, Romeis T, Bölker M, Kahmann R (1995) Multiallelic recognition: Nonself-dependent dimerization of the $\mathrm{bE}$ and $\mathrm{bW}$ homeodomain proteins in Ustilago maydis. Cell 81:73-83

Kämper J, Kahmann R, Bölker M, Ma LJ, Brefort T, Saville BJ, Banuett F, Kronstad JW, Gold SE et al (2006) Insights from the genome of the biotrophic fungal plant pathogen Ustilago maydis. Nature 444:97-101

Larsen P, Nielsen JL, Dueholm MS, Wetzel R, Otzen D, Nielsen PH (2007) Amyloid adhesins are abundant in natural biofilms. Environ Microbiol 9:3077-3090

Leuthner B, Aichinger C, Oehmen E, Koopmann E, Müller O, Müller P, Kahmann R, Bölker M, Schreier PH (2005) A $\mathrm{H} 2 \mathrm{O} 2$-producing glyoxal oxidase is required for filamentous growth and pathogenicity in Ustilago maydis. Mol Genet Genomics 272:639-650

Luderer R, de Kock MJD, Dees RHL, de Wit PJGM, Joosten MHAJ (2002) Functional analysis of cysteine residues of ECP elicitor proteins of the fungal tomato pathogen Cladosporium fulvum. Mol Plant Pathol 3:91-95

Martin F, Aerts A, Ahrén D, Brun A, Danchin EGJ, Duchaussoy F, Gibon J, Kohler A, Lindquist E et al (2008) The genome of Laccaria bicolor provides insights into mycorrhizal symbiosis. Nature 452:88-92

Maurer-Stroh S, Debulpaep M, Kuemmerer N, dela Lopez Paz M, Cristiano Martins I, Reumers J, Morris KL, Copland A, Serpell L et al (2010) Exploring the sequence determinants of amyloid structure using position-specific scoring matrices. Nat Meth 7:237-242

Müller O, Schreier PH, Uhrig JF (2008a) Identification and characterization of secreted and pathogenesis-related proteins in Ustilago maydis. Mol Genet Genomics 279:27-39

Müller O, Kahmann R, Aguilar G, Trejo-Aguilar B, Wu A, de Vries RP (2008b) The secretome of the maize pathogen Ustilago maydis. Fungal Genet Biol 45:S63-S70

Murzin AG, Brenner SE, Hubbard T, Chothia C (1995) SCOP: A structural classification of proteins database for the investigation of sequences and structures. J Mol Biol 247:536-540

Otoo HN, Kyeng GL, Qiu W, Lipke PN (2008) Candida albicans als adhesins have conserved amyloid-forming sequences. Eukaryot Cell 7:776-782

Ponting CP, Schultz J, Milpetz F, Bork P (1999) SMART: Identification and annotation of domains from signaling and extracellular protein sequences. Nucleic Acids Res 27:229-232

Rauceo JM, Gaur NK, Lee KG, Edwards JE, Klotz SA, Lipke PN (2004) Global cell surface conformational shift mediated by a Candida albicans adhesin. Infect Immun 72:4948-4955

Romeis T, Brachmann A, Kahmann R, Kämper J (2000) Identification of a target gene for the bE-bW homeodomain protein complex in Ustilago maydis. Mol Microbiol 37:54-66

Sambrook J, Fritsch EF, Maniatis T (1989) Molecular Cloning : a Laboratory Manual, 2nd edn. Cold Spring Harbor Laboratory Press, Cold Spring Harbor 
Scholtmeijer K, de Vocht ML, Rink R, Robillard GT, Wösten HAB (2009) Assembly of the fungal SC3 hydrophobin into functional amyloid fibrils depends on its concentration and is promoted by cell wall polysaccharides. J Biol Chem 284:26309-26314

Teertstra WR, Deelstra HJ, Vranes M, Bohlmann R, Kahmann R, Kämper J, Wösten HAB (2006) Repellents have functionally replaced hydrophobins in mediating attachment to a hydrophobic surface and in formation of hydrophobic aerial hyphae in Ustilago maydis. Microbiology 152:3607-3612

Teertstra WR, van der Velden GJ, de Jong JF, Kruijtzer JA, Liskamp RM, Kroon-Batenburg LM, Müller WH, Gebbink MF, Wösten HAB (2009) The filament-specific Rep1-1 repellent of the phytopathogen Ustilago maydis forms functional surface-active amyloid-like fibrils. J Biol Chem 284:9153-9159

van Wetter MA, Schuren FHJ, Schuurs TA, Wessels JGH (1996) Targeted mutation of the SC3 hydrophobin gene of Schizophyllum commune affects formation of aerial hyphae. FEMS Microbiol Lett 140:265-269

van Wetter MA, Wösten HAB, Wessels JGH (2000) SC3 and $\mathrm{SC} 4$ hydrophobins have distinct roles in formation of aerial structures in dikaryons of Schizophyllum commune. Mol Microbiol 36:201-210

Vraneš M (2006) Transkriptom-analyse der frühen infektionsphase von Ustilago maydis: Identifikation neuer pathogenitätsrelevanter gene. Dissertation, University of Marburg
Wösten HAB, de Vocht ML (2000) Hydrophobins, the fungal coat unravelled. Biochim Biophys Acta 1469:79-86

Wösten HAB, Willey JM (2000) Surface-active proteins enable microbial aerial hyphae to grow into the air. Microbiology 146:767-773

Wösten HAB, de Vries OMH, Wessels JGH (1993) Interfacial self-assembly of a fungal hydrophobin into a hydrophobic rodlet layer. Plant Cell 5:1567-1574

Wösten HAB, Asgeirsdottir SA, Krook JHH, Drenth JHH, Wessels JGH (1994a) The fungal hydrophobin Sc3p selfassembles at the surface of aerial hyphae as a protein membrane constituting the hydrophobic rodlet layer. Eur J Cell Biol 63:122-129

Wösten HAB, Schuren FHJ, Wessels JGH (1994b) Interfacial self-assembly of a hydrophobin into an amphipathic protein membrane mediates fungal attachment to hydrophobic surfaces. EMBO J 13:5848-5854

Wösten HAB, Bohlmann R, Eckerskorn C, Lottspeich F, Bölker M, Kahmann R (1996) A novel class of small amphipathic peptides affect aerial hyphal growth and surface hydrophobicity in Ustilago maydis. EMBO J 15:4274-4281

Wösten HAB, van Wetter MA, Lugones LG, van der Mei HC, Busscher HJ, Wessels JGH (1999) How a fungus escapes the water to grow into the air. Curr Biol 9:85-88

Zheng Y, Kief J, Auffarth K, Farfsing JW, Mahlert M, Nieto F, Basse CW (2008) The Ustilago maydis Cys2His2-type zinc finger transcription factor Mzr1 regulates fungal gene expression during the biotrophic growth stage. Mol Microbiol 68:1450-1470 